of 1925 , it is not to be numbered among the great earthquakes of California. The epicentre is placed. by the U.S. Coast and Geodetic Survey in lat. $33 \cdot 7^{\circ} \mathrm{N}$, long. $118.9^{\circ} \mathrm{W}$, a point in the San Pedro channel, about twenty-five miles west of San Pedro Point (Science Service, Washington, D.C., March 11). The earthquake was thus probably due to a movement along the submarine San Pedro fault zone. The earthquake of July 28, 1769 , also seems to have been felt most severely along the shore of San Pedro Bay and may therefore have been connected with the same fault zone.

\section{Plastic Materials}

ALтнобgн a large number of new industries dealing with the products of plastic materials have been established in recent years, it is not yet realised the extent to which these 'substitute' materials have nowadays replaced natural products. In order to introduce plastic materials to other industries, as well as to the public, an exhibition was opened by Lord Irwin at the Science Museum, South Kensington, on April 5, which traces the course of the plastics industry from the various raw materials used in the production of plastics to the final product of artificial wood, china, horn and metals. Natural and synthetic resins, cellulose and casein are the principal bases on which the new industries depend and from these has been built up a wide variety of manufactures, ranging from aircraft accessories, buttons, dental instruments, electric insulation, fancy goods, furniture, gramophone records, combs, spectacle cases to scientific instruments and such sports requisites as golf balls and billiard balls. The term 'plastic materials' covers a number of natural and artificial chemical products, the chief property of which is that they can take shape or form under pressure. One of the most interesting features of the exhibition is a room in which the furniture and the surfaces are made entirely of plastic materials. The exhibition will remain open until the end of September.

\section{Announcements}

Wing-Combr. The Hon. Maurice Baring, Prof. W. Langdon Brown, Regius professor of physic in the University of Cambridge, and Prof. H. H. Dodwell, professor of history of the British Dominions in Asia, School of Oriental Studies, have been elected members of the Athenæum Club under the provisions of Rule II of the Club, which empowers the annual election by the committee of a certain number of persons of distinguished eminence in science, literature, the arts, or for public service.

Prof. H. E. Armstrong will deliver the Huxley Memorial Lecture at the Imperial College of Science and Technology, South Kensington, on Thursday, May 4, at 5.30 p.m. His subject will be "Our Need to Honour Huxley's Will".

A David Anderson-Berry gold medal, together with a sum of money amounting to about $£ 100$, will be awarded in July 1935 by the Royal Society of
Edinburgh to the person who, in the opinion of the Council, has recently produced the best work on the nature of $\mathrm{X}$-rays in their therapeutical effect on human diseases. A similar award will be made every three years.

M. Albert Portevin, president of the Société des Ingénieurs Civils de France, will deliver the twenty. third annual May lecture before the Institute of Metals at the Institution of Mechanical Engineers, Storey's Gate, Westminster, S.W.I, on May 10, at 8 p.m. The subject of the lecture will be "Quenching and Tempering Phenomena in Alloys".

Silver medals of the Royal Aeronautical Society have been awarded to Mr. D. L. H. Williams for his work in designing the Fairey long-range monoplane in which Squadron Leader Gayford and Flight Lieutenant Nicholetts made a record non-stop flight to South Africa, and to Mr. A. H. R. Fedden for his work on air-cooled engines, particularly the Bristol Pegasus engine used in the biplane in which Mr. C. F. Uwins recently attained a height of $43,976 \mathrm{ft}$.

Ar the annual general meeting of the Physical Society held on March 17 the following officers were elected: -President, Prof. A. O. Rankine; Vice-President, Prof. W. Wilson; Secretaries, Dr. Allan Ferguson (Papers), Dr. Ezer Griffiths (Business); Foreign Secretary, Prof. O. W. Richardson; Treasurer, Mr. R. S. Whipple; Librarian, Dr. J. H. Brinkworth; New Members of Council, Prof. E. V. Appleton, Dr. L. F. Bates, Dr. L. Hartshorn.

Aт the annual corporate meeting of the Institution of Chemical Engineers, held on February 17, the following officers were elected : President, The Right Hon. the Viscount Leverhulme; Vice-Presidents, Dr. H. Levinstein, Mr. H. Talbot; Hon. Secretary, Mr. H. W. Cremer; Hon. Treasurer, Mr. F. A. Greene; Members of Council, Col. E. Briggs, Mr. H. J. Pooley, Dr. F. S. Sinnatt; Associate-Members, Mr. C. C. H. Brazier, Mr. H. A. S. Gothard. The Osborne Reynolds medal for the year 1932 was presented to Mr. S. G. M. Ure, in recognition of his valuable services to the Institution as honorary editor of the Transactions for the past seven years. The Moulton medal for the best paper read before the Institution during the year was awarded to Dr. C. M. White, for a paper entitled "Fluid Friction and its Relation to Heat Transfer", and the Junior Moulton medal and prize of kooks was awarded to Dr. W. B. Hawes for a paper entitled "Some Sidelights on the Heat Transfer Problem".

Applications are invited for the following appointments, on or before the dates mentioned :-A staff lecturer at the Northern Counties Training College of Domestic Science, Northumberland Road, Newcastleupon-Tyne--The Principal (April 10). A head of the mechanical engineering department of Rutherford Technical College-The Director of Education, Education Office, Northumberland Road, Newcastleupon-Tyne (April 22). 